\title{
Edukacja religijna w poszukiwaniu odpowiedzi na egzystencjalne pytania czlowieka
}

Ludzie na różne sposoby usiłują dotrzeć do satysfakcjonującej ich odpowiedzi na pytania o to, skąd pochodzą, ku czemu zmierzają, jaki jest cel i sens ich życia. Pytania te zazwyczaj nazywamy pytaniami egzystencjalnymi. Odnoszą się one przede wszystkim do początków człowieka i świata, sensu i celu ludzkiego życia, śmierci człowieka czy istnienia moralnego zła. Pytania te są tym trudniejsze, że odpowiedzi na nie, uzyskiwane dzięki czysto naturalnym poszukiwaniom, są niezadowalające. Człowiek dostrzega, jak jego rozum w konfrontacji z tymi pytaniami dochodzi do granicy, której nie jest w stanie przekroczyć. Jej osiągnięcie skłania człowieka do zwrócenia się $\mathrm{w}$ stronę religii $\mathrm{w}$ celu rozstrzygnięcia zasygnalizowanych powyżej dylematów ${ }^{1}$. Ci, którzy decydują się na taki krok, muszą pamiętać, że czerpana z religii wiedza nie jest wynikiem dociekań rozumu, lecz stoi za nią autorytet Boga. Mamy więc do czynienia z innym niż rozumowy sposobem poznania, nazywanym religijnym. Wiedza zdobywana za pośrednictwem

* Ks. prof. dr hab. Zbigniew Marek SJ jest profesorem w Akademii Ignatianum w Krakowie, w Katedrze Andragogiki i Aksjologii Pedagogicznej. Adres: Akademia Ignatianum w Krakowie, Instytut Nauk o Wychowaniu, ul. Kopernika 26, 31-501 Kraków; e-mail: zmarek23@gmail.com.

1 Jarosław Michalski, Edukacja i religia jako źródto rozwoju egzystencjalno-kognitywnego. Studium hermeneutyczno-krytyczne (Toruń: Wydawnictwo UMK, 2004), 111. 
poznania religijnego nie zwalnia jednak nikogo z obowiązku rzetelnego jej wyjaśniania za pomocą rozumu.

Za obecnością religii w procesach edukacyjnych przemawiają ludzkie wysiłki i dążenia do poznawania prawdy. Równocześnie człowiek żyjący w kręgu kultury zachodnioeuropejskiej jest zawieszony między wiarą i niewiarą. Z jednej strony, nie jest on w stanie obojętnie przejść obok religii, a $\mathrm{z}$ drugiej nie zdobywa się na wysiłek odkrycia jej istoty. Nie potrafi określić, gdzie jest jego miejsce i czego winien oczekiwać od życia, a jednocześnie nie ma odwagi do stawiania pytań o drogę, która go zaprowadzi do pełnej prawdy ${ }^{2}$. Zamieszczone poniżej analizy mają na celu odpowiedź na pytanie o zasady obecności religii w procesach edukacyjnych, których celem jest wspieranie człowieka w poszukiwaniu odpowiedzi na kluczowe dla niego pytania, a w konsekwencji wspieranie jego dążeń do nadania spójnego kierunku i kształtu własnemu życiu. Pierwsze dwa punkty poświęcone zostaną jednak wyjaśnieniu istotnych dla tych rozważań kwestii, to jest religii oraz ludzkiego poznania.

\section{Religia}

Dopuszczając możliwość udziału religii w rozstrzyganiu pytań o ludzką egzystencję, niezbędne jest poprawne rozumienie samego terminu „religia”. Według Zofii Zdybickiej we współczesnych jej określeniach zwykle akcentuje się „element subiektywny: poznawczy, wolitywny czy emocjonalny”. Następstwem takiego myślenia o religii jest występowanie u człowieka poczucia konieczności zajmowania określonych postaw czy też wykonywania konkretnych czynności. Przeciwieństwem powyższego, przedmiotowego rozumienia religii jest jej podmiotowe rozumienie. Według niego religia to świadome zwracanie się człowieka do kogoś (czegoś) innego i wyższego niż on sam: Transcendencji (Boga, Absolutu, sacrum). Nawiązywana na tej drodze relacja wyraża się w obustronnym kontakcie i aktywności człowieka, a także przez zajmowanie konkretnych życiowych postaw ${ }^{3}$. Idąc tym tokiem rozumowania, termin ,religia” wyraża realne i osobiste relacje człowieka z Transcendencją - Bogiem, Absolutem. Relacje te charakteryzuje uznanie

2 Johann H. Claussen, Zurück zur Religion. Warum wir vom Christentum nicht loskommen (München: Pantheon Verlag, 2006), 292.

3 Zofia Zdybicka, „Transcendentne odniesienie człowieka”, w: Wychowanie personalistyczne. Wybór tekstów, red. Franciszek Adamski (Kraków: WAM, 2005), 71-72. 
przez człowieka swej zależności od Transcendencji ${ }^{4}$. W rzeczywistości decyzji o ich nawiązaniu człowiek nie podejmuje pod wpływem rzeczowych informacji (nabytej rzetelnej wiedzy), lecz na skutek pragnienia nawiązania z Transcendencją (Bogiem) relacjis. Zaletą tak rozumianej religii w szeroko rozumianym życiu społecznym jest utrzymywanie porządku społecznego szczególnie w sytuacjach granicznych i krańcowych ${ }^{6}$.

W kręgu kultury zachodnioeuropejskiej termin „religia” odnoszony jest głównie do chrześcijaństwa ze względu na jego dominację. Chrześcijaństwo to „religia Osoby” - Trójjedynego Boga7 ; religia objawienia się Boga ${ }^{8}$ ludziom w Jezusie Chrystusie i w mocy Ducha Świętego9. Wiara w Trójjedynego Boga odróżnia chrześcijaństwo od każdej innej formy religijności. Nie wyklucza to punktów stycznych z innymi religiami. Tak na przykład chrześcijanie wespół z Żydami i muzułmanami podobnie wyjaśniają jedno z najbardziej podstawowych pytań człowieka, które dotyczy jego początku. Religie te jednym głosem odpowiadają: Bóg jest stwórcą ludzi i całego świata. Natomiast wyróżniającym chrześcijaństwo w tak formułowanym wyznaniu jest wiara w osobowego, Trójjedynego Boga, który na różne sposoby w ciągu dziejów świata nawiązywał i nawiązuje z ludźmi relacje; Boga, który pozostaje w żywych związkach z całym stworzeniem, a w szczególności z człowiekiem. Chrześcijaństwo przyjmuje istnienie jednej natury i trzech boskich osób: Ojca, Syna i Ducha Świętego. Wyjaśniana treść wiary chrześcijańskiej jest w ścisłym znaczeniu tajemnicą. Wyraża ona wejście człowieka wraz ze swoim życiem na drogę zjednoczenia, wspólnoty życia z żywym

${ }^{4}$ Por. Eugeniusz Sakowicz, Religioznawstwo (Lublin: Polihymnia, 2009), 10; Mieczysław Rusecki, „Wychowanie religijne w rodzinie”, w: Religijno-moralny wymiar rozwoju $i$ wychowania, red. Alina Rynio, Katarzyna Braun, Anna Lendzion, Danuta Opozda (Lublin: Wydawnictwo KUL, 2012), 301.

${ }_{5}^{5}$ Por. Zbigniew Marek, Podstawy i założenia katechetyki fundamentalnej (Kraków: WSFP „Ignatianum”, WAM, 2007), 42.

${ }^{6}$ Anna Walulik, Moderacyjne i synergiczne ksztaltowanie dorostości (Kraków: WSFP „Ignatianum”, WAM, 2011), 44-48.

7 Zagadnienie to przedstawia między innymi: Piotr Liszka, „Personalizm”, w: Leksykon pedagogiki religii, red. Cyprian Rogowski (Warszawa: Verbinum, 2007), 571-576.

${ }^{8}$ Por. Sobór Watykański II, Deklaracja o wolności religijnej (Poznań: Pallottinum, 2002), nr 1; Karl Rahner, Herbert Vorgrimler, „Chrześcijaństwo”, w: Mały słownik teologiczny (Warszawa: Instytut Wydawniczy Pax, 1987), 56-60; Franz König, Jacob Kremer, „Chrześcijaństwo", w: Leksykon religii, red. Hand Waldenfels (Warszawa: Verbinum, 1997), 60.

9 Por. Stanisław T. Zarzycki, „Buddyzm”, w: Leksykon duchowości katolickiej, red. Marek Chmielewski (Kraków: Wydawnictwo M, 2002), 105. 
Bogiem. To z kolei pokazuje, że chrześcijaństwo nie jest systemem „dogmatycznych twierdzeń", lecz sposobem czy też drogą życia ${ }^{10}$. Chrześcijaństwo podkreśla przy tym, że podstawą relacji Boga z ludźmi jest miłość, jaką Bóg obdarowuje wszystkie stworzenia ${ }^{11}$. Dlatego przy poszukiwaniach istoty wiary w Boga należy zwracać uwagę nie tylko na to, w co człowiek wierzy, ale nade wszystko, komu wierzy ${ }^{12}$.

Sama nazwa religii chrześcijańskiej wskazuje na jej związki z osobą Jezusa Chrystusa ${ }^{13}$. Jej wyznawcy - chrześcijanie - wierzą, że szczytem i pełnią Bożego objawienia jest osoba Jezusa Chrystusa, który jest zarówno prawdziwym Bogiem, jak i prawdziwym człowiekiem. W wydarzeniu przyjścia na ziemię Jezusa Chrystusa chrześcijanie upatrują najpełniejszy wyraz miłości Boga do całego stworzenia. Wiara w prawdziwe bóstwo i prawdziwe człowieczeństwo Jezusa przynoszącego ludzkości zbawienie w sposób zasadniczy odróżnia też chrześcijaństwo od każdej innej religii ${ }^{14}$. Podobnie odmienność chrześcijaństwa od innych religii wyraża rozumienie posłannictwa Jezusa, a nade wszystko Jego męki, śmierci na krzyżu i zmartwychwstania. Tego ostatniego wydarzenia nie należy uważać za zwyczajny powrót do życia na ziemi. Jest ono znakiem odniesionego przez Jezusa zwycięstwa nad złem, grzechem i samą śmiercią, które Bóg za Jego pośrednictwem ofiaruje ludziom. Chrześcijaństwo w męce Jezusa na krzyżu widzi realne przywrócenie ludzkości pierwotnego wewnętrznego ładu, który umożliwia dostęp do Boga i udziela daru życia w Jego bliskości i przyjaźni przez całą wieczność. W refleksji nad istotą religii chrześcijańskiej należy podkreślić także fakt dokonywanego przez człowieka wolnego wyboru Boga (wiary). Wiąże się z nim gotowość dochowania Mu wierności, zaufania i posłuszeństwa.

Niekiedy ludziom wydaje się, że Bóg „coś człowiekowi odbiera”, „W czymś go ogranicza”. Istotą tego nieporozumienia jest rozwijany zwłaszcza w XIX wieku pogląd o tym, że Bóg jest „nieprzyjacielem natury ludz-

10 Por. Stefan Orth, „Was heißt glauben?“, Herder Korrespondenz 8 (2013): 380-381.

${ }^{11}$ Por. König, Kremer, „Chrześcijaństwo”, 65; Joachim Kunstmann, Rückkehr der Religion. Glaube, Gott und Kirche neu verstehen (Gütersloh: Gütersloher Verlagshaus, 2010), 25.

12 Roman Schulz, Wykłady z pedagogiki ogólnej, t. II: O integralna wizję człowieka i jego rozwoju (Toruń: Wydawnictwo UMK, 2007), 81.

13 Por. Zbigniew Marek, Religia pomoc czy zagrożenie dla edukacji? (Kraków: WAM, 2014), 43n.

${ }^{14}$ Urlich H. J. Körtner, Wiederkehr der Religion?Das Christentum zwischen neuer Spiritualität und Gottvergessenheit (Gütersloh: Gütersloher Verlagshaus, 2006), 15. 
kiej"15. Jego wyrazicielami byli między innymi Zygmund Freud, Fryderyk Nietzsche czy Karol Marks. W przekonaniu Michaela J. Buckleya, będzie on ulegać marginalizacji i zanikowi między innymi dlatego, że wspomniani autorzy nie dowodzą prawdy ateizmu. Oni po prostu lekceważą wszelkie racjonalne podstawy poglądów religijnych. W tym sposobie myślenia Buckley dostrzega sprzeczność zachodzącą „między człowiekiem a bóstwem między racjonalnością a irracjonalnością, ludzkim rozwojem a hamującymi złudzeniami, między wiedzą i wiarą"16. Uważa też, że ta rzekoma wrogość pomiędzy badaniami naukowymi i religią jest fałszywa. Jeśli bowiem w myśleniu człowieka będzie mieć miejsce odrzucanie wnioskowania i krytycznego rozumowania, instytucji, nauki i filozofii na rzecz uczucia, emocji, autonomicznych „emocjonalnych wspólnot” i zawoalowanej niejasności; jeśli nadto człowiek będzie przekonany, że instytucje i tradycje, wnioskowanie i spekulacja myślowa są składnikami i wymogami prawdziwej religii oraz prawdziwego doświadczenia religijnego, to myślenie takie prowadzić będzie do zgubnych dla niego skutków ${ }^{17}$.

\section{Poznanie}

W rozwoju człowieka ważną rolę odgrywa zdolność poznania. Poznaniem nazywana jest świadoma czynność uzyskiwania informacji, uchwycenia istnienia lub własności czegoś; rezultat tej czynności w postaci pojęć, sądów i rozumowań; stany i procesy umysłowe cechujące się wewnętrznym uobecnianiem świata zewnętrznego, dokonujące się w spostrzeganiu, myśleniu, pamięci i wyobrażeniach ${ }^{18}$. Wiedzę zdobywaną za pośrednictwem rozumu i badań empirycznych może w wielu przypadkach ubogacić wiedza zdobyta za pośrednictwem ,,poznania religijnego" (wiary) ${ }^{19}$, które występuje obok ,poznania naturalnego" (intelektualnego). Podmiotem poznania religijnego (teologicznego) jest osoba ,wraz ze wszystkimi władzami poznawczy-

15 Por. Michael J. Buckley, Ateizm w sporze z religia (Kraków: WAM, 2009), 134-179.

16 Tamże, 170-171.

17 Tamże, 240.

18 Piotr Kawalec, „Poznanie”, w: Encyklopedia katolicka, t. XVI, red. Edward Gigilewicz (Lublin: TN KUL, 2012), 157.

19 Pojęcie to stosowane jest w języku religijnym. Wiele uwagi temu zagadnieniu poświęcił papież Jan Paweł II w Encyklice Fides et ratio o relacjach między wiarą a rozumem z dnia 14 września 1998 roku. 
mi; jako poznająca musi być ona otwarta na rzeczywistość nadprzyrodzoną, która jawi się przed nią, a także aktywna w tym sensie, że chce ją poznać w sposób wolny od uprzedzeń i jest gotowa do poniesienia szczególnego wysiłku poznawczego"20. Na tej podstawie wolno twierdzić, że poznanie religijne zawiera w sobie nową jakość poznawczą, gdyż umożliwia przekraczanie barier ograniczających poznanie naturalne. Poznanie religijne, które jest wspierane naukami teologicznymi, poszerza zakres wiedzy człowieka za pośrednictwem objaśnień rzeczywistości czerpanych z treści religijnych ${ }^{21}$. Ta droga poznania wymaga rezygnacji z własnego doświadczenia i wglądu na rzecz przyjęcia określonych zdań i poglądów, za którymi stoi autorytet i świadectwo samego Boga.

Wyjaśnienia te wskazują też na zasadniczą różnicę między poznaniem naturalnym i poznaniem religijnym wywoływaną dostępem do wiedzy. $\mathrm{O}$ ile w poznaniu naturalnym człowiek posługuje się zdolnością poznawczą płynącą z rozumu, który dostarcza mu wiedzy i pewności wynikającej z własnego (ludzkiego) poznania (wglądu i doświadczenia), o tyle źródłem poznania religijnego jest Boże Objawienie, w którym człowiek poszukuje i odnajduje wyjaśnienia swych egzystencjalnych pytań ${ }^{22}$. Za pośrednictwem Bożego objawienia człowiek jest w stanie odkryć dialog, jaki Bóg w ciągu wieków prowadzi z człowiekiem ${ }^{23}$. Objawienie Boże dostarcza bowiem nowego, niekoniecznie empirycznie stwierdzalnego, objaśnienia sensu ludzkiej egzystencji. Nazywa się je manifestacją obecności Istoty, która sama się przedstawia jako Absolutny podmiot, Stwórca i Zbawiciel człowieka jednocześnie. O tym, czy poznanie religijne zostanie zaakceptowane, decyduje swą wolną decyzją człowiek, podobnie podejmuje on też suwerenne decyzje o wyborze Boga i Jego autorytetu (wiary) ${ }^{24}$. Istotę tego dwojakiego porządku poznania papież Jan Paweł II upatrywał w tym, że „obok poznania właściwego ludzkiemu rozumowi, który ze swej natury zdolny jest dotrzeć nawet do samego Stwórcy, istnieje poznanie właściwe wierze. Jest to poznanie prawdy opartej

${ }^{20}$ Marian Rusecki, „Poznanie w teologii”, w: Encyklopedia katolicka, t. XVI, red. Edward Gigilewicz (Lublin: TN KUL, 2012), 160.

${ }^{21}$ Por. Marek, Religia, 49n.

22 Jan Paweł II, Encyklika Fides et ratio, nr 9.

${ }^{23}$ Por. Benedykt XVI, Posynodalna adhortacja apostolska Verbum Domini o Słowie Bożym w życiu i misji Kościoła, nr 9.

${ }^{24}$ Hans Waldenfels, O Bogu, Jezusie Chrystusie i Kościele dzisiaj. Teologia fundamentalna w kontekście czasów obecnych (Katowice: Księgarnia św. Jacka, 1993), 317. 
na rzeczywistości samego Boga, który się objawia, a więc prawdy niezawodnej, ponieważ Bóg się nie myli ani nie zamierza zwieść człowieka"25. Przyjęcie takiego sposobu rozumowania wymaga wiary wyrażającej zaufanie do osoby - w chrześcijaństwie osoby Boga, który najpełniej objawił siebie w osobie Jezusa Chrystusa.

Poznanie religijne, w odróżnieniu od poznania naturalnego, pomaga człowiekowi zrozumieć rzeczywistość, której nie można poznać drogą doświadczeń empirycznych oraz intelektem; objaśnia rzeczywistość, która jest niedostępna poznaniu naturalnemu. Wprawdzie obecność poznania naturalnego i religijnego może się pojawiać we „wszelkich doświadczeniach typu rozwojowego, to jednak z większym prawdopodobieństwem wystąpi ona w sytuacjach i doświadczeniach o charakterze wyjątkowym, niecodziennym, rzadkim, czyli takich, które dotyczą spraw tajemniczych, kwestii ostatecznych, tzn. mających zasadnicze znaczenie w życiu i rozwoju człowieka"'26. Ten stan rzeczy wymaga więc umiejętności korzystania z obu postaci poznania oraz respektowania zakresów rzeczywistości, którą każda z nich objaśnia.

Poznanie religijne umożliwia przyjęcie za prawdę tego, czego ludzki umysł do końca nie jest w stanie ogarnąć; co Bóg objawia o sobie, o człowieku i o całej rzeczywistości, także tej niewidzialnej, niepojętej, niewyobrażalnej. W tym sensie poznanie religijne poszerza horyzont ludzkiego poznania. Pozwala dotrzeć do tajemnicy, w jaką zanurzona jest jego egzystencja. Nie oznacza to oczywiście, że poznanie religijne udziela osobie zadowalających odpowiedzi na wszystkie ludzkie pytania. Poznanie to daje natomiast możliwość poszerzania wiedzy o sobie i świecie. Akceptacja poznania religijnego jest więc zgodą człowieka na to, że doświadczenie i naturalna refleksja nie dostarczają zadowalających wyjaśnień spraw, na które poszukuje on odpowiedzi.

Kiedy więc pojawia się kwestia poznania naturalnego i religijnego, nie należy zakładać istniejącej między nimi rywalizacji: obie formy wzajemnie się przenikają i uzupełniają. Każda ma własną przestrzeń, w której się realizuje ${ }^{27}$. Co więcej, prawda czerpana z poznania religijnego angażuje rozum po to, by przy jego udziale móc zgłębiać jej sens i znaczenie dla ludzkiej egzystencji. Należy natomiast mieć na uwadze możliwość występowania nieporozumień, związanych z niewłaściwym korzystaniem z poznania

\footnotetext{
25 Jan Paweł II, Encyklika Fides et ratio, nr 8.

${ }^{26}$ Schulz, Wyktady, 129.

27 Jan Paweł II, Encyklika Fides et ratio, nr 17; Waldenfels, O Bogu, 461.
} 
religijnego. Dzieje się tak na skutek zacierania bądź wykluczania zakresów poznania albo źródeł każdej z jego form. Ma to miejsce wówczas, gdy człowiek w poszukiwaniach prawdy zdaje się na samowolę swego osądu. Następstwem tego działania jest ocena rzeczywistości, której dokonuje wyłącznie w oparciu o kryteria pragmatyczne: wiedzę doświadczalną i podporządkowaną technice. „Rezultat jest taki, że - zamiast wyrażać jak najlepiej dążenie do prawdy - rozum chyli się ku samemu sobie pod brzemieniem tak rozległej wiedzy, przez co z dnia na dzień staje się coraz bardziej niezdolny do skierowania uwagi ku wyższej rzeczywistości i nie śmie sięgnąć po prawdę bytu" 28 . Godząc się na wskazane zalety poznania religijnego, można mówić o tym, że religia ubogaca procesy edukacyjne właściwym sobie ukazywaniem świata i człowieka z perspektywy Boga. Owo poznanie jest dla człowieka nie tylko wsparciem w lepszym zrozumieniu świata i miejsca, jakie w nim zajmuje, ale też pomocą w pełniejszym rozumieniu siebie i świata, a nadto w osiąganiu życia, którym jest nieśmiertelność, życie w szczęściu i miłości.

\section{Religia dla edukacji}

Akceptacja religii mechanicznie nie wprowadza w życie człowieka istotowych zmian. Dostarcza natomiast nowych możliwości postrzegania i poznawania rzeczywistości. Aby do tego doszło, człowiek musi podejmować wysiłek, umożliwiający lepsze poznanie świata i rządzących nim praw. Wsparciem dla niego jest edukacja ${ }^{29}$, w tym także edukacja religijna. Pojęcie „edukacja” uważane jest za nadrzędne i znaczeniowo bliskie terminom „wychowanie” i „kształcenie” ${ }^{30}$. Zostają nim objęte procesy społeczne, które pozwalają osobie włączać się w kulturę ${ }^{31}$. Zazwyczaj bywa ono dookreślane, „co wskazuje na odrębność i specjalizację oddziaływań zewnętrznych

28 Jan Paweł II, Encyklika Fides et ratio, nr 9.

${ }^{29}$ Definicja edukacji jest powszechnie akceptowana. Wciąż jednak dyskutuje się nad jej istotą. Por. Piotr Tomasik, Religia $w$ dialogu z edukacja (Warszawa: Wydawnictwo Salezjańskie, 2004), 54-136.

${ }^{30}$ Por. Michalski, Edukacja, 51; Wincenty Okoń, Słownik pedagogiczny (Warszawa: PWN, 1981), 66; Gerald L. Gutek, Filozoficzne i ideologiczne podstawy edukacji (Gdańsk: Gdańskie Wydawnictwo Psychologiczne, 2003), 14.

31 Gutek, Filozoficzne, 14. 
oraz towarzyszącą im refleksję wewnętrzną" "32. Zachodzące procesy łączymy z wpływami, jakie są wywierane bądź to przez osobę, bądź większą grupę społeczną na kogoś innego. Wpływy te dostarczają impulsów do kształtowania własnej tożsamości i odrębności w życiu społecznym ${ }^{33}$. Edukacja ma zatem sprzyjać integralnemu rozwojowi osoby poprzez udzielane jej wsparcie, którym przyczynia się do formowania (zmiany, rozwijania) jej zdolności bądź zmiany ich jakości ${ }^{34}$. Można więc mówić, że edukacja obejmuje wszystkie te działania, które umożliwiają „stawanie się człowiekiem” przy holistycznym i kompleksowym patrzeniu na osobę ${ }^{35}$.

Bliskie terminowi „edukacja” jest pojęcie „edukacji religijnej”. Ma ona za zadanie ubogacać i poszerzać horyzonty poznawcze człowieka, osiągane przy pomocy poznania naturalnego, wprowadzając nowy rodzaj poznania, nazywanego „poznaniem religijnym”. Jego obecność nie zachwieje fundamentami edukacji choćby dlatego, że zakresy obu form poznania, jak o tym poniżej, są od siebie niezależne i dotyczą różnych sfer ludzkiego życia. Natomiast jego uwzględnienie daje możliwości szerszego podejścia do kwestii edukacyjnych. Na tym polu wiele do zdziałania ma pedagogika religii, która uczy poprawnego objaśniania egzystencjalnych sytuacji człowieka w świetle wiary ${ }^{36}$. Należy przy tym dopowiedzieć i to, że ogólność pojęcia edukacji domaga się chronienia go przed zacieśnianiem do działan o wymiarze technologicznym i adaptacyjnym czy informacyjnym. W działaniach tych o wiele ważniejsze wydaje się położenie akcentu na dialog, gdyż w czasie jego trwania dochodzi między uczestnikami do wymiany zdań nad zdobytymi doświadczeniami ${ }^{37}$.

Jeśli więc dialog edukacyjny, o którym mówimy, zachodzi między nauczycielem i uczniami, to wówczas można mówić o dialogu edukacyjnym opartym na zasadach towarzyszenia pedagogicznego. Jego właściwością jest udostępnianie partnerom własnych doświadczeń czy przekonań po to, by łatwiej im było zrozumieć myślenie innych. Przybiera on różne formy

32 Janusz Krysztofik, Anna Walulik, „Edukacja religijna i jej miejsce w ponowoczesności. Współczesne ujęcie edukacji religijnej”, Studia Katechetyczne 12 (2016): 36.

${ }^{33}$ Por. Zbigniew Kwieciński, Socjopatologia edukacji (Olecko: Mazurska Wszechnica Nauczycielska, 1995), 13n.

${ }^{34}$ Por. Bogusław Milerski, Religia a szkoła. Status edukacji religijnej w szkole w ujęciu ewangelickim (Warszawa: Chrześcijańska Akademia Teologiczna, 1998), 125.

35 Schulz, Wykłady, 53.

36 Szerzej: Marek, Religia, 67n.

37 Por. Milerski, Religia, 123-124. 
i odbywa się na różnych płaszczyznach życia. Jednym z obszarów takiej wymiany jest rzeczywistość religijna, która może ubogacać procesy edukacyjne $^{38}$. Pokazuje to, że religia jako pozytywna siła społeczna spełnia ważne role społeczne ${ }^{39}$. Spostrzeżenie to dostarcza podstaw do określenia edukacji religijnej. Jej zadanie polega na wspieraniu osoby w nabywaniu umiejętności samodzielnego interpretowania ludzkiej egzystencji za pośrednictwem treści religijnych po to, by „pomóc uczniowi w rozumieniu siebie i świata w kontekście wyznawanej przez niego religii; jako zdolności interpretowania rzeczywistości w świetle Bożego Objawienia"40.

Janusz Krysztofik i Anna Walulik zwracają uwagę, że

edukacja religijna tworzy przestrzeń dialogu i komunikacji, która wymaga uzupełnienia o analizę dyskursywności i swoistej racjonalności komunikacyjnej. Oznacza to, że nie jest ona edukacją milczącą, a tym bardziej nie jest formą teologii milczenia. Jest raczej formą zbiorowego uczestniczenia w przestrzeni codzienności rozumianej jako nauczanie i uczenie się ${ }^{41}$.

Sytuacja taka domaga się podjęcia konkretnych działań, które tworzyć będą podstawy tego rodzaju dialogu. Jego prowadzenie możliwe jest w przypadku posiadania rzetelnej wiedzy, także religijnej. Wiedza bowiem umożliwia człowiekowi poznawanie nawet najbardziej skomplikowanej rzeczywistości. Nie inaczej jest w przypadku egzystencjalnych pytań. Naturalną drogą w nabywaniu wiedzy jest rozum i empiria. Umożliwiają one logiczne tłumaczenie i uzasadnianie odkrywanej rzeczywistość. Jednocześnie jednak podejmowane poszukiwania uświadamiają człowiekowi własną ograniczoność i niemożność zaspokojenia wszystkich swych potrzeb ${ }^{42}$.

Przyjmując, że termin „,edukacja religijna” „opisuje zjawisko nauczania i uczenia się opartego na źródłach religijnych" "33, które łączy w sobie dwa

${ }^{38}$ Charakterystyczne rysy dialogu edukacyjnego omawia Marian Śnieżyński, Sztuka dialogu. Teoretyczne założenia a szkolna i akademicka rzeczywistość (Kraków: Wydawnictwo Naukowe Akademii Pedagogicznej, 2008), 94-113; Marian Śnieżyński, Dialog edukacyjny (Kraków: Wydawnictwo Naukowe Papieskiej Akademii Teologicznej, 2001), 17n.

39 Dariusz Tułowiecki, Bez Boga, Kościoła i zasad? (Kraków: Wyd. Petrus, 2012), 37-39.

${ }^{40}$ Krysztofik, Walulik, „Edukacja”, 40.

41 Tamże, 43.

${ }^{42}$ Paul M. Zulehner, „Religia jako mega trend”, Keryks 1 (2003): 22; Stanisław Zięba, „Człowiek. 2. Pochodzenie”, w: Leksykon pedagogiki religii, red. Cyprian Rogowski (Warszawa: Verbinum, 2007), 93-99.

${ }^{43}$ Krysztofik, Walulik, „Edukacja”, 47. 
elementy: ludzkie doświadczenie ${ }^{44}$ i Boże objawienie ${ }^{45}$, rodzi się pytanie $\mathrm{o}$ wkład religii w procesy edukacyjne. Za znaczącą $\mathrm{w}$ tej kwestii wydaje się być otwartość osoby na rzeczywistość niematerialną - duchową. Na znaczenie tego aspektu zwraca uwagę Krystyna Ablewicz, która zauważa, że w literaturze podejmującej problematykę wychowania trudno jest doszukać się takich pojęć jak: „duch”, „rozwój duchowy”, „duchowość”. Według niej ta nieobecność ducha

została wywołana wtórnie, jako konsekwencja metodologicznego rozbicia całościowo doświadczanego fenomenu procesu wychowania człowieka, wzmacniając tym samym utrwalany kulturowo i mentalnie kartezjański dualizm, rozdwajający człowieka na substancję cielesną i substancję (rzecz) myślącą, nazywaną $\mathrm{w}$ tym przypadku duszą ${ }^{46}$.

Dlatego też przywoływanie w edukacji rzeczywistości niematerialnej w sposób znaczący zmienia ludzkie życie między innymi przez to, że umożliwia włączanie się w kulturę, uczy aktywności na rzecz innych, czym wspiera rozwój wewnętrzny osoby. Zachodzące przy tej okazji procesy nazywamy rozwojem duchowym, któremu bliski jest termin „duchowość”.

Duchowość jest terminem antropologicznym, który odwołuje się do właściwości natury człowieka: doświadczenia transcendencji, które umożliwia poznanie osoby oraz jej duchowego istnienia. Pierwotnie terminem tym

${ }^{44}$ Przez doświadczenie rozumiemy zarówno rzeczywistość zmysłową, jak i duchową, zewnętrzną oraz wewnętrzną, która zawsze występuje jako jednostkowy i indywidualny konkret. Oznacza to, że doświadczenia nie można ,wymusić”; można je tylko gromadzić. W nich osoba wyraża nie tylko swój intelektualny, ale także afektywno-emocjonalny stosunek do poznawanej rzeczywistości, co wywołuje wrażenia bezpośredniości i pierwotności, a także odniesienie do kogoś bądź czegoś innego. Doświadczenia budzą zainteresowanie, skłaniają do stawiania pytań, wyzwalają nadzieję, a także budzą niepokoje, refleksję i różnego rodzaju oceny moralne, a także pragnienie przekształcania własnego życia. To zaś oznacza, że pozostawiają trwały ślad przez poruszenie głębszych sfer osobowości. Por. Marek, Religia, 83.

${ }^{45}$ Chrześcijanie przyjmują, że niewidzialny i niepojęty Bóg z własnej inicjatywy objawił się człowiekowi. Termin ten wyraża zarówno czynność objawienia, jak też jego przedmiot. Przedmiotem objawienia jest sam Bóg i Jego wola. Bóg objawiał się ludziom na przestrzeni dziejów nie po to, aby zaspokoić ich ciekawość, lecz by zaprosić ludzi do życia w szczęściu przez całą wieczność. Por. Antoni Paciorek, „Objawienie”, w: Leksykon pedagogiki religii, red. Cyprian Rogowski (Warszawa: Verbinum, 2007), 466-471.

46 Por. Krystyna Ablewicz, „(Nie)obecność ducha w wychowaniu człowieka. Z filozofii kultury Bogdana Nawroczyńskiego”, Horyzonty Wychowania 6 (2007): 59-60, 65. 
posługiwano się w znaczeniu religijnym. Miało ono oznaczać postępowanie sprzyjające wzrostowi duchowemu ${ }^{47}$. Współcześnie w literaturze coraz częściej podejmuje się temat duchowości bez odniesień do TranscendencjiBoga. Łączy się ją nie tylko z praktyką życia duchowego (sens subiektywny) i usystematyzowaną refleksją nad nim (sens obiektywny), ale też z praktyką życia bez odwoływania się do Transcendencji - Boga ${ }^{48}$. Tę postać duchowości często nazywa się „,duchowością naturalną"49. Wprawdzie duchowość nie istnieje jako byt fizyczny, posiada jednak istnienie bogatsze i szlachetniejsze - duchowe, właściwe poznaniu i miłości ${ }^{50}$. Jest uważana za termin prosty, niedefiniowalny ${ }^{51}$, który objaśnia egzystencję i dążenia osoby do życia, szczęścia oraz miłości ${ }^{52}$. Wyraża „wspólnotę sensu wartości, sensu rządzącego określonymi strukturami. Mogą być to sensy życia indywidualnego, sensy sytuacyjne, ale też i korporacyjne, narodowe, religijne"s3. Dlatego też określa się ją mianem wyboru zobowiązania i zaangażowania wobec wszystkiego, co istnieje $\mathrm{e}^{54}$.

Duchowości przypisuje się zdolność kształtowania zarówno stylu życia, jak i prądów kulturowych oraz sposobu sprawowania kultu. Oznacza zatem formę życia, która opiera się na akceptowaniu nadrzędnej wartości, jaką dla

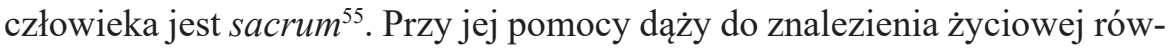
nowagi, harmonii w życiu osobistym, jak również społecznym i w swych

${ }^{47}$ Marek Chmielewski, „Duchowość”, w: Leksykon duchowości katolickiej, red. Marek Chmielewski (Karków: Wydawnictwo M, 2002), 226; por. James Wiseman, Historia duchowości chrześcijańskiej. Wybrane zagadnienia (Kraków: WAM, 2009), 18-21.

${ }^{48}$ Hermann Lombaerts, „Edukacja z perspektywy europejskiej”, Horyzonty Wychowania 2 (2002): 169.

${ }^{49}$ Lidia Marszałek, Duchowość dziecka. Znaczenia - perspektywy - konteksty w pedagogice przedszkolnej (Warszawa: Szkoła Wyższa im. Bogdana Jańskiego, 2013), 51-52.

${ }^{50}$ Jarosław Horowski, Wychowanie moralne wedlug pedagogiki neotomistycznej (Torun: Wydawnictwo Naukowe UMK, 2015), 203; por. Władysław Zuziak, Aksjologia Louisa Lavelle ‘a wobec ponowoczesnego kryzysu wartości (Kraków: WAM, 2012), 72-74.

${ }^{51}$ Por. Chmielewski, „Duchowość”, 229.

${ }^{52}$ Por. Marszałek, Duchowość, 27n.; Luis F. Ladaria, Wprowadzenie do antropologii teologicznej (Kraków: WAM, 2002), 14-15; Thomas Meurer, „Duchowość jako zamiennik religii? Wyprawy w mgliste pogranicze religii i duchowości”, Keryks 10 (2011): 158.

53 Ablewicz, „(Nie)obecność”, 77.

${ }^{54}$ James L. Griffith, Melissa E. Griffith, Odkrywanie duchowości w psychoterapii (Kraków: WAM, 2008), 45; por. Wiseman, Historia, 21-25.

${ }_{55}$ Por. Stanisław Witek, „Duchowość religijna”, w: Encyklopedia katolicka, t. IV, red. Romuald Łukaszyk i in. (Lublin: TN KUL, 1989), 330-331. 
relacjach z Bogiem ${ }^{56}$. Takie określenia duchowości pozwalają nazwać ją zbiorem postaw, zwyczajów (tradycji) i wartości preferowanych przez konkretnego człowieka. Zbiór ten kreśli „drogę postępowania”, promuje wizję życia, wyzwala refleksję nad rozumieniem codzienności, uczy szacunku do świata i wyzwala nadzieję osiągnięcia czegoś „większego”, czegoś, co zaspokoi pragnienia człowieka ${ }^{57}$. Nastawienie to wyraża za pośrednictwem pracy, myślenia, symboli, mowy, sztuki, zabawy, kultury, nauki itp. ${ }^{58}$

Niezależnie jednak od tego, czy duchowość będziemy odnosić do Boga, czy też nie, współtworzą ją świadomość (poznanie), emocjonalność (uczucia) oraz wartości (w tym religijne) wraz z przyjmowaną i akceptowaną ich hierarchią ${ }^{59}$. Wynika $\mathrm{z}$ tego, że nie jest ona czymś statycznym, lecz aktywnym. Co więcej, „będąc pojęciem wielowymiarowym, obejmuje zarówno pogłębione życie religijne, w tym również różne światopoglądy, jak i kompetencje poznawcze rozumienia siebie i świata oraz posiadanie świadomie kształtowanego wymiaru moralnego" ${ }^{\circ 0}$. Stanowi zatem właściwość człowieka, która ,istnieje sama przez się, jest przedmiotem samorzutnych przejawów myśli, mowy, ocen, dążeń, twórczości i porywów ponad doczesność i zmysłowość". Dlatego też czynniki duchowe, które ją kształtują, wymagają nie tylko rozwoju, ale też właściwego nastawienia osoby ku Logosowi pełnemu prawdy i łaski ${ }^{61}$. Oczywiste wydaje się przy tym, że zwracanie uwagi na znaczenie duchowości człowieka dla edukacji nie wyczerpuje problemu. Jak się wydaje, duchowość nadaje edukacji nowy wymiar i dlatego warto się nad nią pochylać w kontekście podejmowania problematyki edukacyjnej.

\section{Zasadność obecności religii w edukacji}

Edukacja religijna sprzyja rozwojowi człowieka, wspierając go w osiąganiu integralnej dojrzałości. Możliwości takie wynikają z tego, że poten-

56 Jerzy Bagrowicz, Towarzyszyć wzrastaniu. Z dyskusji o metodach i środkach edukacji religijnej młodzieży (Toruń: Wydawnictwo UMK, 2006), 183.

57 David. L. Fleming, Czym jest duchowość ignacjańska? (Kraków: WAM, 2013), 5-6; por. Meurer, „Duchowość”, 158.

58 Marszałek, Duchowość, 33.

${ }^{59}$ Chmielewski, „Duchowość”, 229.

${ }^{60}$ Janusz Surzykiewicz, „Religia, religijność i duchowość jako zasoby osobowe i kapitał społeczny w pedagogice społecznej/pracy socjalnej”, Pedagogika Społeczna 1 (2015): 31.

${ }^{61}$ Stefan Kunowski, Podstawy współczesnej pedagogiki (Łódź: Wydawnictwo Salezjańskie, 1981), 215. 
cjalności duchowe - intelektualne i wolitywne, twórcze i religijne - tkwią w naturze ludzkiej. Ich aktualizacja nie odbywa się jednak mechanicznie, a oczekuje na autonomiczną decyzję człowieka. Co więcej, jak tłumaczy Stanisław Gałkowski, do podjęcia takiej decyzji człowiek potrzebuje zewnętrznego wsparcia, ponieważ ,jest bytem przygodnym, a więc zarówno w swoim istnieniu, jak i realizowaniu swoich potencjalności potrzebuje współdziałania innych osób, pomocy całego społeczeństwa i w ostateczności Boga". Owo wspieranie dotyczy zarówno potrzeb somatycznych, jak też duchowo-psychicznych ${ }^{62}$. Tak udzielana wieloraka pomoc ma na celu takie ukierunkowanie postępowania człowieka, by można było nazwać je moralnym. Udział w tym mają procesy nazwane wychowaniem moralnym, a znaczącą rolę może spełniać w nich religia.

Istotę wychowania moralnego stanowią wszelkiego rodzaju inicjatywy, których celem jest uczenie wychowanka wybierania powszechnie uznawanego dobra i odrzucanie $z^{\prime}{ }^{63}$. Dlatego wychowania moralnego nie należy uważać za jedną z wielu dziedzin, jeden z wielu składników wszechstronnego wychowania, na które składa się wychowanie fizyczne, umysłowe, społeczne, kulturalne czy światopoglądowe. Wychowania moralnego nie powinno się stawiać na tej samej płaszczyźnie dlatego, że ze swej istoty jest ono niczym innym, jak doskonaleniem go we wszystkich dziedzinach życia i działalności. Lepiej jest uważać je za swego rodzaju wspólny mianownik wszystkich zakresów oddziaływań wychowawczych, dlatego że od osoby postępowania moralnego oczekujemy we wszystkich zakresach jej życia ${ }^{64}$.

Same oddziaływania wychowawcze winny zmierzać do świadomego wywoływania w osobie trwałych zmian w zakresie jej stosunku do świata i innych ludzi oraz przekonań i postaw, a także przyjmowanych wartości i kreślonego celu życia. Zmiany te odnoszą się do dwóch jego wymiarów: indywidualnego i społecznego. Wychowanie moralne ma kształtować człowieka, doskonalić jego życie i działalność sprzyjającą osiąganiu dojrzałej osobowości. Chodzi więc w nim nie tyle o coraz pełniejsze rozumienie własnych powinności moralnych, ale o wzrost empatii, utożsamianie się z coraz

${ }^{62}$ Stanisław Gałkowski, Dlugomyślność. Wprowadzenie do filozofii wychowania (Kraków: Akademia Ignatianum, WAM, 2016), 71.

${ }^{63}$ Por. Wofgang Brezinka, Wychowanie i pedagogika $w$ dobie przemian kulturowych (Kraków: WAM, 2005), 15.

${ }^{64}$ Zbigniew Marek, Podstawy wychowania moralnego (Kraków: WSF-P „Ignatianum”, WAM, 2005), 62. 
większą grupą osób i innych stworzeń ${ }^{65}$. Natomiast pomijanie bądź redukowanie tych założeń prowadzić będzie do organizowania wychowania połowicznego i mało skutecznego, a nierzadko bezmyślnego (do tresury) i przez to społecznie szkodliwego ${ }^{66}$.

Wychowanie moralne ma wspierać osobę w osiąganiu dojrzałości. „Dojrzałość” w pedagogice łączona jest ze zdolnością „bycia odpowiedzialnym" we wszystkich zakresach życia, a więc w zakresie poznawczym, emocjonalnym i moralnym ${ }^{67}$. Procesom tym towarzyszy odkrywanie świata duchowego, wewnętrznego. Na tej drodze dochodzi do przekraczania granic zdeterminowania człowieka w wymiarze instynktowo-popędowym. Jest to możliwe dzięki zdolności wykraczania poza świat potrzeb biologicznych, samozachowawczych i seksualnych, a także potrzeb psychicznych związanych z potrzebami bezpieczeństwa, uznania, miłości, poznawania, myślenia. Całość tego procesu umożliwia rozumienie i wkraczanie w rzeczywistość duchową, której istotą jest odkrywanie sensu życia i nawiązywanie relacji z Transcendencją ${ }^{68}$.

Poziom osiąganej dojrzałości weryfikują przyjmowane przez osobę postawy, których nabywanie jest zadaniem wychowania moralnego. Przez postawę moralną rozumiemy względnie stałe zachowanie, które wyraża się w gotowości podmiotu do pozytywnych lub negatywnych reakcji intelektualno-orientacyjnych - poznawczych, emocjonalno-motywacyjnych oraz behawioralnych wobec jej przedmiotu. Zachowania te są powiązane z psychiczno-społecznymi potrzebami, pragnieniami i dążeniami osoby. One też dostarczają jej komponentów uczuciowo-motywacyjnych do zajmowania określonych postaw. Ich kształtowanie w dużej mierze warunkowane jest doświadczeniami, jakie osoba gromadzi od zarania swego życia.

Procesom kształtowania postaw towarzyszy przekonanie osoby o posiadaniu intelektualnej pewności oraz realności bądź też słuszności funkcjonowania jakiegoś przedmiotu czy zaistnienia określonego stanu rzeczy. Osiągany na tej drodze poziom pewności o istnieniu takiej rzeczywistości określa poziom dojrzałości moralnej (moralności autonomicznej) ${ }^{69}$ determinowanej zarówno rozumieniem istoty postępowania moralnego, jak też podejmowa-

${ }^{65}$ Gałkowski, Dlugomyślność, 80.

${ }^{66}$ Por. Marek, Podstawy wychowania, 28.

${ }^{67}$ Por. Marek, Religia, $117 \mathrm{n}$.

${ }^{68}$ Por. Waldenfels, O Bogu, 279-285.

${ }^{69}$ Por. Regina Łapińska, Maria Żebrowska, „Wiek dorastania”, w: Psychologia rozwojowa dzieci i młodzieży, red. Maria Żebrowska (Warszawa: PWN, 1986), 443-444. 
nymi działaniami, jakie inspiruje posiadana wiedza ${ }^{70}$. Sam proces osiągania moralności autonomicznej obejmuje trzy działania: socjalizację, interioryzację i absolutyzację ${ }^{71}$. Roman Murawski dopowiada przy tym, że jeśli takie procesy nie dokonają się u wychowanków, wówczas zmierzać będą do spychania związanych z nimi problemów na peryferie osobowości ${ }^{72}$.

Samo respektowanie zasad określających specyfikę procesów wychowania moralnego pokazuje, że osoba musi posiąść odpowiednią przestrzeń do tego, by swoje doświadczenia weryfikować w kategoriach moralnych. Założenia te chrześcijaństwo konkretyzuje wsparciem osoby w podejmowanych przez nią wysiłkach rozwijania wrodzonych zdolności fizycznych, intelektualnych i moralnych po to, by faktycznie miał miejsce harmonijny jej rozwój. Dlatego ważne jest, by wychowanek wielokrotnie otrzymywał możliwości gromadzenia doświadczeń związanych z kierowaniem się bądź odrzuceniem przekazywanych mu wartości. Sytuacja ta nie dopuszcza powstrzymywania się od jakichkolwiek działań wychowawczych i pozostawienie wychowanka bez wsparcia, które można nazwać towarzyszeniem pedagogicznym.

Za istotę towarzyszenia pedagogicznego, którego postawy chrześcijaństwo upatruje w personalizmie ${ }^{73}$, uważamy podejmowane przez wychowawcę działania zmierzające do wyzwalania w wychowanku poczucia własnej podmiotowości, odkrywanej nie tylko z perspektywy naturalnej, ale też nadnaturalnej - Boga. Zabieg ten umożliwia osobie odkrywanie w religii możliwości pełniejszego postrzegania swego życia, jak również przyjmowania nie tylko świata wartości naturalnych, ale i religijnych. Oznacza to, że pedagogika towarzyszenia nie zamierza alienować człowieka z rzeczywistości, w jakiej żyje, lecz inspiruje do jej odkrywania w świetle treści religii chrześcijańskiej. Nadawana przez pedagogikę towarzyszenia wychowaniu nowa jakość związana jest więc $\mathrm{z}$ rozumieniem godności osoby i dowartościowaniem jej podmiotowości. Nie bez znaczenia dla tak rozumianego towarzyszenia jest

${ }^{70}$ Gałkowski, Dlugomyślność, 189.

${ }^{71}$ Roman Murawski, „Problematyka wieku dorastania”, w: Teoretyczne założenia katechezy młodzieżowej, red. Roman Murawski (Warszawa: Wydawnictwo Salezjańskie, 1989), $22-23$.

${ }^{72}$ Roman Murawski, „Dorastający. Założenia podręczników dla katechezy i ucznia, klasa I, zeszyt I”, w: Jestem świadkiem Chrystusa w Kościele. Podręcznik metodyczny do religii dla I klasy liceum i technikum (Kraków: WAM, 2002), 43.

${ }_{73}$ Por. Zbigniew Marek, Pedagogika towarzyszenia. Perspektywa tradycji ignacjańskiej (Kraków: Akademia Ignatianum, 2017). 
religia odwołująca się do osobowych relacji z Bogiem. Relacje takie dostarczają nowych motywów i inspiracji do wysiłku przejmowania i uznawania za własne pożądanych postaw i zachowań wychowanka. Poszerza ono także zakres refleksji nad procesem wychowania i religijnym objaśnianiem natury i godności człowieka, a w końcu umożliwia też jego wychodzenie poza własną ograniczoność oraz kierowanie się ku celowi ostatecznemu, jakim jest życie bez końca w dobru i miłości ${ }^{74}$. Działania te w przypadku chrześcijaństwa zostają nadto ubogacone wartościami religijnymi, które dostarczają dodatkowego uzasadnienia potrzeby kształtowania w sobie pożądanych społecznie postaw ze względu na ostateczne przeznaczenie człowieka. Jest ono ukazywane jako życie „w” Bogu i ,z” Bogiem przez całą wieczność.

Powyższe myślenie i działanie wydaje się być skuteczne pod warunkiem, że poszczególne doznania wychowawcze będą porządkowanie i scalanie przez wszystkie podmioty tego procesu: rodziców, pedagogów, młodzież oraz inne środowiska wychowawcze ${ }^{75}$. Dlatego też udzielane wychowankom wsparcie wychowawcze winno charakteryzować odchodzenie od hierarchicznego wydawania rozkazów, swoistej tresury, a także od bezmyślnego ich wykonywania, gdyż tylko w takich warunkach możliwy jest integralny rozwój osoby. W toku takiego myślenia o edukacji jest do przyjęcia teza, iż czerpane z religii chrześcijańskiej wsparcie wychowawcze może być początkiem drogi prowadzącej do moralności autonomicznej, nazywanej też dojrzałością moralną. Jej właściwością jest identyfikowanie się z ,wartością moralną", którą jest przede wszystkim osoba. Przyjęcie i zaakceptowanie religijnego oglądu świata, w tym także relacji łączących człowieka z Bogiem, wyznacza konkretne zasady działalności wychowawczej, które domagają się respektowania poznanych i akceptowanych wartości promowanych przez religię.

\section{$* * *$}

Biorąc pod uwagę fakt, iż człowiek winien być moralnym w całokształcie swego życia: w swych dociekaniach intelektualnych, sferze emocjonalnej i wolitywnej, a także w sferze życia biologicznego, mówiąc o udziale religii w procesach edukacyjnych z dużym uproszczeniem mówimy o jej znaczeniu dla sfery moralnej, co nie znaczy, że nie ma ona znaczenia dla innych wymiarów ludzkiego życia. Szczególnie jest to widoczne przy udzielaniu odpo-

\footnotetext{
${ }^{74}$ Marek, Pedagogika.

75 Por. Wojciech Cichosz, Pedagogia wiary we wspótczesnej szkole katolickiej (Warszawa:
} TYPO 2, 2010), 191-203. 
wiedzi na egzystencjalne pytania o pochodzenie człowieka, sens jego życia czy też jego przeznaczenie. Warto przy tym pamiętać, że człowiek dzięki posiadanej wolności jest w stanie odpowiedzi te przyjmować, ale i odrzucać. Dlatego też o udziale religii w procesach edukacyjnych należy mówić w kategoriach „możliwości” poszerzania ludzkiej wiedzy i ludzkich kompetencji poznawczych. W konsekwencji przy poszukiwaniu odpowiedzi na egzystencjalne pytania człowieka winno się zwracać uwagę na istotę religii, także na zakres udzielanych przez nią odpowiedzi na egzystencjalne pytania człowieka. To, że nie każdy człowiek przyjmuje i akceptuje takie odpowiedzi, jeszcze nie znaczy, że one są fałszywe. Należy przy tym podkreślić, że religia (chrześcijaństwo) nie rości sobie prawa do objaśniania wszystkich spraw interesujących człowieka. Zadaniem chrześcijaństwa jest jedynie objaśnianie szeroko rozumianej ludzkiej egzystencji rozpatrywanej w kontekście związków łączących go z Bogiem. Oznacza to, że objaśnia ono jedynie ten zakres ludzkiego życia, którego nie jest w stanie wytłumaczyć przy pomocy dociekań rozum. W tych też kontekstach winniśmy szukać i formułować odpowiedź na pytanie o to, czy religia jest dla edukacji pomocą, partnerem służącym dobru i rozwojowi osoby czy raczej zagrożeniem.

\section{Religious Education in the Search for Answers to Existential Human Questions (Summary)}

There are various ways in which man tries to reach a satisfactory answer to his questions about where he comes from, what he is aiming at, what the purpose and meaning of his life is. These questions are usually called existential questions. Experience shows that human reason in confrontation with these questions comes to a limit that it cannot cross. These experiences make man turn to the "forces" that exist outside of him, including religion. This situation raises the question of the extent to which religion can complement human ignorance. When looking for answers to these kinds of questions, we will look at the relationship between religion and education, the contribution of religion to human cognition and education. Reflection on these relationships shows that religion, correctly understood, provides man with a new knowledge of human existence in the context of his union with God. This means that only religion explains the sphere of human life that cannot be explained by rational reasoning alone. It is in these contexts that we should seek and formulate an answer to the question whether religion is an aid for education, a partner leading to the good and the development of a person, or rather a threat. 
Keywords: education; religious education; religion; cognition; religious cognition.

\section{Edukacja religijna w poszukiwaniu odpowiedzi na egzystencjalne pytania czlowieka (Streszczenie)}

Człowiek na różne sposoby usiłuje dotrzeć do satysfakcjonujących go odpowiedzi na pytania o to, skąd pochodzi, ku czemu zmierza, jaki jest cel i sens jego życia. Pytania te zazwyczaj nazywamy pytaniami egzystencjalnymi. Doświadczenie pokazuje, że rozum człowieka w konfrontacji z tymi pytaniami dochodzi do granicy, której nie jest w stanie przekroczyć. Doświadczania te powodują, że człowiek zwraca się ku „siłom” istniejącym poza nim, w tym także do religii. Sytuacja ta wyzwala pytanie, w jakiej mierze jest ona w stanie uzupełnić ludzką niewiedzę. Przy poszukiwaniu odpowiedzi na tego rodzaju pytania zwrócimy uwagę na związki zachodzące pomiędzy religią i edukacją, wkład religii w ludzkie poznanie i edukację. Refleksja nad zachodzącymi między nimi związkami pokazuje, że religia - poprawnie rozumiana - dostarcza człowiekowi nowej wiedzy o ludzkiej egzystencji w kontekście związków łączących go z Bogiem. Oznacza to, że jedynie ona objaśnia ten zakres ludzkiego życia, którego nie jest w stanie wytłumaczyć przy pomocy dociekań rozum. W tych też kontekstach winniśmy szukać i formułować odpowiedź na pytanie o to, czy religia jest dla edukacji pomocą, partnerem służącym dobru i rozwojowi osoby czy raczej zagrożeniem.

Słowa kluczowe: edukacja; edukacja religijna; religia; poznanie; poznanie religijne.

\section{Bibliografia}

Ablewicz, Krystyna. „(Nie)obecność ducha w wychowaniu człowieka. Z filozofii kultury Bogdana Nawroczyńskiego". Horyzonty Wychowania 6 (2007): 57-79. Bagrowicz, Jerzy. Towarzyszyć wzrastaniu. $Z$ dyskusji o metodach i środkach edukacji religijnej mlodzieży. Toruń: Wydawnictwo UMK, 2006.

Brezinka, Wolfang. Wychowanie i pedagogika $w$ dobie przemian kulturowych. Kraków: WAM, 2005.

Buckley, Michael J. Ateizm w sporze z religia. Kraków: WAM, 2009. 
Chmielewski, Marek. „Duchowość”. W: Leksykon duchowości katolickiej, red. Marek Chmielewski, 226-232. Kraków: Wydawnictwo M, 2002.

Cichosz, Wojciech. Pedagogia wiary we wspótczesnej szkole katolickiej. Warszawa: TYPO 2, 2010.

Claussen, Johann H. Zurück zur Religion. Warum wir vom Christentum nicht loskommen. München: Pantheon Verlag, 2006.

König, Franz, Jacob Kremer. „Chrześcijaństwo”. W: Leksykon religii, red. Hans Waldenfels, 59-67. Warszawa: Verbinum, 1997.

Fleming, David L. Czym jest duchowość ignacjańska? Kraków: WAM, 2013.

Gałkowski, Stanisław. Długomyślność. Wprowadzenie do filozofii wychowania. Kraków: Akademia Ignatianum, WAM, 2016.

Griffith, James L., Melissa E. Griffith. Odkrywanie duchowości w psychoterapii. Kraków: WAM, 2008.

Gutek, Gerald L. Filozoficzne i ideologiczne podstawy edukacji. Gdańsk: Gdańskie Wydawnictwo Psychologiczne, 2003.

Horowski, Jarosław. Wychowanie moralne wedtug pedagogiki neotomistycznej. Toruń: Wydawnictwo Naukowe UMK, 2015.

Kawalec, Piotr. „Poznanie”. W: Encyklopedia katolicka, t. XVI, red. Edward Gigilewicz, 157-159. Lublin: TN KUL, 2012.

Körtner, Urlich H. J. Wiederkehr der Religion? Das Christentum zwischen neuer Spiritualität und Gottvergessenheit. Gütersloh: Gütersloher Verlagshaus, 2006.

Krysztofik, Janusz, Anna Walulik. „Edukacja religijna i jej miejsce w ponowoczesności. Współczesne ujęcie edukacji religijnej”. Studia Katechetyczne 12 (2016): 35-50.

Kunowski, Stefan. Podstawy współczesnej pedagogiki. Łódź: Wydawnictwo Salezjańskie, 1981.

Kunstmann, Joachim. Rückkehr der Religion. Glaube, Gott und Kirche neu verstehen. Gütersloh: Gütersloher Verlagshaus, 2010.

Kwieciński, Zbigniew. Socjopatologia edukacji. Olecko: Mazurska Wszechnica Nauczycielska, 1995.

Ladaria, Luis F. Wprowadzenie do antropologii teologicznej. Kraków: WAM, 2002.

Liszka, Piotr. „Personalizm”. W: Leksykon pedagogiki religii, red. Cyprian Rogowski, 571-576. Warszawa: Verbinum, 2007.

Lombaerts, Hermann. „Edukacja z perspektywy europejskiej”. Horyzonty Wychowania 2 (2002): 165-179.

Łapińska, Regina, Maria Żebrowska. „Wiek dorastania”. W: Psychologia rozwojowa dzieci i młodzieży, red. Maria Żebrowska. Warszawa: PWN, 1986.

Marek, Zbigniew. Pedagogika towarzyszenia. Perspektywa tradycji ignacjańskiej. Kraków: Akademia Ignatianum, 2017. 
Marek, Zbigniew. Podstawy i założenia katechetyki fundamentalnej. Kraków: WSFP „Ignatianum”, WAM, 2007.

Marek, Zbigniew. Podstawy wychowania moralnego. Kraków: WSF-P „Ignatianum", WAM, 2005.

Marek, Zbigniew. Religia pomoc czy zagrożenie dla edukacji? Kraków: WAM, 2014.

Marszałek, Lidia. Duchowość dziecka. Znaczenia-perspektywy - konteksty w pedagogice przedszkolnej. Warszawa: Szkoła Wyższa im. Bogdana Jańskiego, 2013.

Meurer, Thomas. „Duchowość jako zamiennik religii? Wyprawy w mgliste pogranicze religii i duchowości”. Keryks 10 (2011): 147-159.

Michalski, Jarosław. Edukacja i religia jako źródło rozwoju egzystencjalno-kognitywnego. Studium hermeneutyczno-krytyczne. Torun: Wydawnictwo UMK, 2004.

Milerski, Bogusław. Religia a szkoła. Status edukacji religijnej w szkole w ujęciu ewangelickim. Warszawa: Chrześcijańska Akademia Teologiczna, 1998.

Murawski, Roman. „Dorastający. Założenia podręczników dla katechezy i ucznia, klasa I, zeszyt I". W: Jestem świadkiem Chrystusa w Kościele. Podręcznik metodyczny do religii dla I klasy liceum i technikum, 23-48. Kraków: WAM, 2002.

Murawski, Roman. „Problematyka wieku dorastania”. W: Teoretyczne założenia katechezy młodzieżowej, red. Roman Murawski, 23-48. Warszawa: Wydawnictwo Salezjańskie, 1989.

Okoń, Wincenty. Stownik pedagogiczny. Warszawa: PWN, 1981.

Orth, Stefan. „Was heißt glauben?“. Herder Korrespondenz 8 (2013): 380-381.

Paciorek, Antoni. „Objawienie”. W: Leksykon pedagogiki religii, red. Cyprian Rogowski, 466-471. Warszawa: Verbinum, 2007.

Rahner, Karl, Herbert Vorgrimler. „Chrześcijaństwo”. W: Maty stownik teologiczny, 56-60. Warszawa: Instytut Wydawniczy Pax, 1987.

Rusecki, Marian. „Poznanie w teologii”. W: Encyklopedia katolicka, t. XVI, red. Edward Gigilewicz, 159-160. Lublin: TN KUL, 2012.

Rusecki, Mieczysław. „Wychowanie religijne w rodzinie”. W: Religijno-moralny wymiar rozwoju i wychowania, red. Alina Rynio, Katarzyna Braun, Anna Lendzion, Danuta Opozda, 299-335. Lublin: Wydawnictwo KUL, 2012.

Sakowicz, Eugeniusz. Religioznawstwo. Lublin: Polihymnia, 2009.

Schulz, Roman. Wykłady z pedagogiki ogólnej. T. II: O integralna wizję człowieka i jego rozwoju. Toruń: Wydawnictwo UMK, 2007.

Surzykiewicz, Janusz. „Religia, religijność i duchowość jako zasoby osobowe i kapitał społeczny w pedagogice społecznej/pracy socjalnej”. Pedagogika Spoteczna 1 (2015): 23-71.

Śnieżyński, Marian. Sztuka dialogu. Teoretyczne założenia a szkolna i akademicka rzeczywistość. Kraków: Wydawnictwo Naukowe Akademii Pedagogicznej, 2008. 
Tomasik, Piotr. Religia w dialogu z edukacją. Warszawa: Wydawnictwo Salezjańskie, 2004.

Tułowiecki, Dariusz. Bez Boga, Kościoła i zasad? Kraków: Wydawnictwo Petrus, 2012.

Waldenfels, Hans. O Bogu, Jezusie Chrystusie i Kościele dzisiaj. Teologia fundamentalna w kontekście czasów obecnych. Katowice: Księgarnia św. Jacka, 1993.

Walulik, Anna. Moderacyjne i synergiczne ksztaltowanie dorosłości. Kraków: WSFP „Ignatianum”, WAM, 2011.

Wiseman, James. Historia duchowości chrześcijańskiej. Wybrane zagadnienia. Kraków: WAM, 2009.

Witek, Stanisław. „Duchowość religijna”. W: Encyklopedia katolicka, t. IV, red. Romuald Łukaszyk i in., 330-334. Lublin: TN KUL, 1989.

Zarzycki, Stanisław T. „Buddyzm”. W: Leksykon duchowości katolickiej, red. Marek Chmielewski, 99-107. Kraków: Wydawnictwo M: 2002.

Zdybicka, Zofia. „Transcendentne odniesienie człowieka”. W: Wychowanie personalistyczne. Wybór tekstów, red. Franciszek Adamski, 68-88. Kraków: WAM, 2005.

Zięba, Stanisław. „Człowiek. 2. Pochodzenie”. W: Leksykon pedagogiki religii, red. Cyprian Rogowski, 93-99. Warszawa: Verbinum, 2007.

Zulehner, Paul M. „Religia jako mega trend”. Keryks 1 (2003): 21-35.

Zuziak, Władysław. Aksjologia Louisa Lavelle`a wobec ponowoczesnego kryzysu wartości. Kraków: WAM, 2012. 